\title{
Lumen
}

Selected Proceedings from the Canadian Society for Eighteenth-Century Studies

\section{Imaging the Unspeakable and Speaking the Unimaginable: The 'Description' of the Slave Ship Brookes and the Visual Interpretation of the Middle Passage}

\section{Marcus Wood}

Volume 16, 1997

Freedom and Boundaries

Émancipation et frontières

URI : https://id.erudit.org/iderudit/1012450ar

DOI : https://doi.org/10.7202/1012450ar

Aller au sommaire du numéro

Éditeur(s)

Canadian Society for Eighteenth-Century Studies / Société canadienne d'étude du dix-huitième siècle

ISSN

1209-3696 (imprimé)

1927-8284 (numérique)

Découvrir la revue

Citer cet article

Wood, M. (1997). Imaging the Unspeakable and Speaking the Unimaginable: The 'Description' of the Slave Ship Brookes and the Visual Interpretation of the Middle Passage. Lumen, 16, 211-245. https://doi.org/10.7202/1012450ar 


\title{
15. Imaging the Unspeakable and Speaking the Unimaginable: The 'Description' of the Slave Ship Brookes and the Visual Interpretation of the Middle Passage
}

\begin{abstract}
There is a limit at which the practice of an art becomes an affront to affliction. Let us not forget this . . . what have you done to gain knowledge of the disaster?
\end{abstract}

Maurice Blanchot

This article analyzes images, and writings related to these images, which give representations of the Atlantic slave trade in the eighteenth and nineteenth centuries. The central focus is the representation of the middle passage. This area of the visual representation of slavery has been isolated for analysis because it occupied a position of unique importance during the first wave of English abolition activity from 1780 to 1807. During the succeeding sixty years, the middle passage remained central to representations of slavery by British, French, and American abolitionists, and to the representation of slavery in popular print culture generally. ${ }^{1}$

From the founding of the Society for Effecting the Abolition of the Slave Trade (SEAST) in 1787 to the passage of the bill for abolition of the English slave trade in 1807, the middle passage was a central battleground for pro- and anti-slavery propagandists. Having decided on a strategy of limiting their campaign to slave trade abolition, not general emancipation, abolition propaganda attempted to prove that the trade was not economic and that the conditions on board ship and the mortality rates for slaves were appalling. Of equal importance was the proof that conditions and mortality rates for British sailors were also bad. The latter argument was intended to disprove the standard pro-slavery 
position that the slave trade constituted the nursery of British seamanship. $^{2}$

One image dominated the representation of the physical conditions endured by Africans on board slavers during the middle passage (Fig. 1). The famous 'Description of a Slave Ship' (hereafter 'Description') represented in cross section, front view and side view, and in a series of overviews of both slave decks, the manner in which slaves could be legally packed onto the Liverpool slaver the Brookes. ${ }^{3}$ A partial version of the image was first designed in a crude engraving entitled 'Plan of an African Ship's Lower Deck with Negroes in the proportion of only One to a Ton' (hereafter 'Plan') produced by the Plymouth Committee of the SEAST in December 1788 and published in January 1789. The 'Plan' was then taken up by the London Committee of the SEAST and developed into its most widely disseminated form, the 'Description' (Fig. 1). This image was published by James Philips in London in the spring of 1789 and caused an immediate and international sensation. ${ }^{4}$ This print was the most famous, widely-reproduced, and widely-adapted image representing slave conditions on the middle passage ever made. It was published simultaneously as a single-sheet copper engraving in an edition of 1,700, and in a run of 7,000 from a wood-engraved impression; both versions were distributed as broadsides. In the same year that it was published in England, a large edition was also adapted for the French market and distributed in Paris by Thomas Clarkson, and an American adaptation was mass marketed in Philadelphia and led to adaptations in the Northern free states. ${ }^{5}$

The genesis, contemporary reception, and subsequent graphic development of the 'Description' provide the central concern of this paper. It is argued that this image supports an abolitionist cultural agenda which dictated that slaves were to be visualized in a manner that emphasized their total passivity and their status as helpless victims. It is further argued that the fascination this print exerted on its readership can only be understood if it is considered in terms of its relation to post-Enlightenment developments in technical drawing, to established biblical narrative traditions, and finally to aesthetic codes rooted in Western decorative art. It is also a central premise of this paper that the task of explaining why the middle passage was represented the way it was bears not only on the past but also on the present. The conclusion consequently considers how the 'Description' has been deployed in popular publishing in Enland and America over the past two centuries. Twentieth-century adaptations suggest that Western society's memory of the middle passage may still be dominated by eighteenth-century English abolitionist cultural models. 
Mechanisms for denial, and for misremembering, still operate within the European inheritance of the middle passage. Henry Louis Gates sees white perceptions of the middle passage as obscuring the understanding of how cultural transference from African civilizations to those of the new world slave communities may have operated:

The notion that the middle passage was so traumatic that it functioned to create in the African a tabula rasa of consciousness is as odd as it is a fiction, a fiction that has served many economic orders and their attendant ideologies. The full erasure of the traces of cultures as splendid, as ancient, and as shared by the slave traveller as the classic cultures of traditional West Africa, would have been extraordinarily difficult. (4)

This affirmation raises many questions about the nature of descriptions of blacks by English abolitionists in the late eighteenth century, and about descriptions of the middle passage in particular. It also challenges the interpretative history of such descriptions. The theory of a 'tabula rasa' of black culture, the anti-personality to which Gates wonderingly and angrily refers, was, in its most blatant manifestations, the creation of the propagandists of the pro-slavery lobby in England. Pro-slavery configurations of the middle passage provided one of the contexts which dictated the form of the 'Description' as a piece of anti-slave propaganda. Leading pro-slavery propagandists, the most persuasive of whom were Robert Norris, Edward Long, Robert Bisset, and Bryan Edwards, produced a body of work which, when it confonted the cultural inheritance of slaves at all, emphasized the corruption, barbarity, and above all heathenism of African peoples. The middle passage was dealt with primarily as an economic phenomenon. ${ }^{6}$

Another effective way of mispresenting the middle passage was to construct the African slave, and the slave trade, within distorting mythological and artistic conventions. Such disguises could take bizarre and extreme forms. A particularly powerful example, which combines poetic and graphic forms, occurs in Bryan Edwards's History Civil and Commercial, of the British Colonies in the West Indies. In a lyric preface to his chapter detailing the history and development of the African Atlantic slave trade, Edwards reprints Isaac Teale's poem 'The Sable Venus; an Ode' (2: 27-33) together with an elaborate illustrative engraving designed by Thomas Stothard (Fig. 2). Here, the black slave woman's experience of the middle passage is mythologized into a version of the Birth of Venus. The text describes the middle passage by conventions of peculiarly reconstituted venereal metaphor. The rape of slave women is reconstructed in terms of a triumph of the sable Venus over the slave owners and traders, who are ironically portrayed as her 
powerless victims (2: 32-33). The process begins when Triton, the God of the sea, in order to win Venus, 'assumed the figure of a tar' (2: 31); the result of their interracial union at sea is a hybrid Cupid. The accompanying plate shows the black Venus as the symbolic representative of all female slaves. She has a cloud of white cherubs hovering about her and is magically wafted across the Atlantic. The slave ship is transformed into a beautiful scallop shell pulled by frolicking dolphins. This late Baroque extravaganza is, in narrative and descriptive terms, antithetical to the diagrammatic and factual 'Description.' The print in Edwards's History is particularly significant in view of the fact that explicitly pro-slavery visual propaganda representing the middle passage is almost non-existent in the late eighteenth century. ${ }^{7}$ But, intriguing as it is in providing an example of the elaborate lengths to which pro-slavery denial of the middle passage could go, Edwards's image was exceptional and had no popular impact.

The development of genuinely popular images attempting description of the slaves during the middle passage was the achievement not of the pro-slavery lobby but of the abolitionists. Yet the images they produced obey a series of symbolic and narrative codes which deny the slave cultural representation. On 22 May 1787, the London Committee of the SEAST was set up. ${ }^{8}$ They rapidly turned their attention to the systematic production of propaganda which drew on every available area of contemporary reprographic technology, and which was particularly inventive in terms of the way it generated visual propaganda. The two central images planned at committee level by the SEAST for mass reproduction and international distribution, the 'Description' and the SEAST's official 'Seal,' were instantly influential, maintaining their centrality in the slavery debate in England and America up until the end of the American Civil War. The seal of the SEAST (Fig. 3), with its representation of a kneeling enchained male African beneath the question 'Am I not a man and a Brother?', was reproduced as the heading to a great number of anti-slavery publications, as stationery: in books, prints, oil paintings, and newspaper headlines, and as a ceramic figurine. In its manifestation as a mass-produced Wedgewood ceramic medallion the image became so generally fashionable in the late 1780 s and early 1790 s as to be worn as a brooch or hairpin by society ladies, and incorporated into the lids of snuff boxes. ${ }^{9}$ What this image shares with abolition propaganda which takes the middle passage as its central focus is a rhetoric which conforms, to a frightening extent, to Gates's description of erasure. The black as cultural absentee, the black as a blank page for white guilt to inscribe, emerged as a necessary pre-condition for polemic against the slave trade.

From the mid-1780s to the early 1790 s the symbolic and narrative core of abolition propaganda consisted of descriptions of the middle passage. 
In pamphlets, books, journals, and in the eyewitness accounts given by, or taken from, sailors and submitted during the interminable hearings of the consecutive slave bills in the Commons, a litany of horrors was continually recited, imagined, and re-invented (Craton et al 38-50; Substance 27-117).

The slave had to be presented in a certain way if his/her cause were to stimulate notions of guilt and culpability in an educated English audience, while at the same time not frightening them off through fear or disgust. Torture and extreme suffering were presented through the personal testimony of white witnesses. Some of these accounts involved protacted descriptions of the most harrowing violence against women and children. ${ }^{10}$ Perhaps equally effective, however, were representations which emphasized the dehumanizing commodification of the slaves through an uncompromising objectivity. The attempt to produce detached accounts generated literary and pictorial representations of the slave which did not acknowledge the cultural history, aesthetics, morality, sexuality, religion, or revolutionary desire for independence which the enslaved Africans brought with them. Perhaps the most extreme written example of white superscription of the black experience of the middle passage was produced by the ex-slave captain, and fashionable London divine, John Newton in his Thoughts Upon the African Slave Trade. Newton, several decades after his experience as a witness of the middle passage, came up with a bibliographic metaphor: 'the slaves lie in two rows, one above the other, on each side of the ship, close to each other, like books upon a shelf. I have known them so close, that the shelf would not, easily, contain one more' (Thoughts 19). ${ }^{11}$ Newton's cold metaphor seems to include both the economics of the trade and the factual reports of the abolitionists. In its emphasis on a library-like order, a display obscene in its seemliness, Newton's metaphor suggests a verbal equivalent of the 'Description.'

The idealizing and abstracting tendencies both of Newton's simile and the 'Description' are highlighted if they are set beside the only surviving eyewitness image describing the condition of slaves in a full-packed ship. This is a water-colour made by a young English naval officer, Lieutenant Godfrey Meynell (Fig. 4). It obliterates the linear clarity of the "Description," revealing nothing but a horrible mess. The drawing was made in 1846, off the coast of West Africa, and depicts the state of slaves on the captured Spanish slaver, the Albanoz. The drawing was made thirty-nine years after abolition of the British slave trade and fourteen years after the abolition of slavery in the British sugar colonies. This was a period when national self-doubt and self-loathing over British domination of the slave trade had been effaced and a self-aggrandizing mythology reinscribed. The British Navy's African slave patrols were 
presented as the glorious product of the 1807 abolition bill. The celebration of Britain's disinterested philanthropy allowed for the erection of a pantheon of white abolitionists (Wilberforce, Clarkson, Sharpe, Macaulay) and erasure of national guilt through the active suppression of Spanish, American, and Portuguese slave trading. The capture of each foreign slave ship affirmed British enlightenment and disguised the memory of the two hundred years of British domination of the slave trade. ${ }^{12}$

Meynell's drawing has an ungainly power perhaps all the more emphatic in view of the fact that no visual eyewitness account of an 'English' slave cargo (from before 1807) has survived. It is a work which avoids the basic tropes exemplified in Sir J. Noel Paton's Capture of a Slave Ship (Fig. 5). ${ }^{13}$ In Paton's work, white angelic British tars, bathed in a celestial light, reach down to the slaves, who strike classical poses of despair as they wallow, mimicking lost souls in the infernal regions. Emotion is at fever pitch and a very British mercy is at hand. The leading rescuer reaches down a bared arm, the finger reaching out like Michelangelo's God creating Adam, with the forearm tattooed with the Crown and anchor.

In Meynell's drawing (Fig. 4) no white liberating presence is depicted. The slaves have some freedom of movement, in dark corners and crevices, or precariously perched upon rafters and narrow areas of makeshift floor; they appear left to fend for themselves in the misery and the gloom, fitted in around bales of cloth and barrels, their status as cargo self-evident, their powerlessness emphasized by the fact that there is not a chain in sight. Instead of a maritime prison, with ordered ranks of manacled captives, there is the effect of a shanty town, a haphazard world where depth and colour have been obliterated and where humanity forms part of a seething jumble of goods which will only be extricated, sorted, and polished up on arrival. Fatigue, ennui, discomfort, and sheer depression are the primary impressions. Not one figure remotely resembles the recumbent lines of the Brookes. The marshalled diagrammatics of the 'Description' are dispersed, to be replaced with an artistically primitive white representation of suffering chaos.

Meynell's image is a private witnessing, the visual equivalent of a diary entry, and it is worth asking whether it possesses an equivalent descriptive power to that of the 'Description.' Newton's metaphor and the 'Description' both perhaps suggest that it is necessary to go beyond attempts at empathetic emotionalism in order to provide an image which is appropriate to registering the process of the middle passage. The danger of such an unemotional approach, however, is that it projects an alienating passivity onto the slave. The 'Description' can be read as preempting suffering; the middle passage becomes a living death, a 
trauma during which the slave is stripped of his/her personality and reduced to something less than human. In emphasizing so exclusively the dehumanization of the slaves the 'Description' can be seen as enforcing the mythologies of white economy to which Gates alludes. In the rigour, and the almost abstract elegance, of their arrangement, the slaves appear as a pattern rather than as people. The figures are not merely culturally reduced but wiped clean of cultural association.

To understand how the 'Description' was made, however, and what it meant to contemporaries, it is vital to remember that the work is embedded in the facts of the Liverpool slave trade. It represents not an abstract idea but a real boat, the Brookes, trading out of Liverpool. This boat was first selected by the SEAST Committee in Plymouth as the fitting subject for an illustrated broadside, and then, using more detailed facts and measurements, by the London Committee.

The graphic authority of the 'Description' results, to a large degree, from the fact that it evolved out of a precise style of naval architecture. This comes out clearly if the 'Plan' produced by the Plymouth Committee in 1788 is compared to the London 'Description' of 1789. The formal and stylistic differences between the two versions have never been considered; yet a detailed comparison is worth making, because it provides insights into what qualities gave the final version such force over contemporary audiences.

The Plymouth 'Plan' is crude and rather simple; it presents a single overview or 'plan' of the main slave deck. The slaves are all drawn vertically; they are not packaged efficiently to follow the lines of the ship. The image is also confused in terms of its depiction of the slave bodies by the incorporation of the kneeling slave from the Abolition 'Seal,' who is printed below the image of the ship. This sentimentalized figure, encircled by a symbolic manacle and cat [whip], introduces a set of visual codes which destabilizes the dehumanized and almost abstract depiction of the slave bodies above. In the 'Description' the seal has been erased, while the ship itself has now been drawn up according to a precise set of measurements. These measurements are of a completely different nature from the crude rule of thumb proportions upon which the single view of the Plymouth 'Plan' was based.

It is difficult to establish who actually drew the final version of the 'Description.' The first London Committee minute to refer to the 'Description' makes it clear that the responsibility for designing the new version fell to five members: 'Resolved. That it is the opinion of this Committee that a description of a Slave Ship with a Plan and Sections be prepared and that the following gentlemen be appointed to execute the same. Mr James Philips, Mr. Harrison, Mr. Hoare, Revd. Mr. Clarkson' (Abolition Committee Minutes 2: 17 March). Neither this entry, nor any of 
the many subsequent minutes reporting on the progress and final printing of the 'Description,' makes any mention of the Plymouth 'Plan.' Thomas Clarkson, however, in his History of the Rise, Progress and Accomplishment of the Abolition of the African Slave-Trade by the British Parliament (hereafter History) states that the original design was sent to London from Plymouth:

William Ellford ... a chairman of the Plymouth Committee, sent up for inspection an engraving of a plan and section of a slave-ship, in which the bodies of the slaves were seen stowed in the proportion of one to a ton. This happy invention gave all those who saw it, a much better idea than they could otherwise have had of the horrors of their transportation. (2: 28-29).

Clarkson also goes on, however, to spell out the very different nature of the two designs, and is unambiguous about the superiority of the later version: 'The committee at Plymouth had been the first to suggest the idea; but that in London had now improved it' (2: 111).

Clarkson goes on to give an account of how the plan was designed. He states that the detailed list of ship measurements quoted at the bottom of the 'Description,' from which the second version of the description was drawn up, were the work of a professional sailor, one Captain Perry of the Royal Navy. He was sent on a Government mission to Liverpool to bring back a report on slave ships and presented a series of detailed admeasurements of vessels as part of his report before the House of Commons. The Brookes was chosen simply because it was at the head of Perry's alphabetical list (2: 112-13). When the plan came to be developed out of this information it could consequently be drawn using the most advanced techniques of naval architecture. Then, using the equally precise space limitations set out in Dolben's Bill for the stowage of slaves, it was possible to work out exactly how many slaves the ship could hold. Dolben's Bill was purportedly humanitarian, for the first time setting legal restrictions upon the number of slaves to be carried, allocating a minimum space to each. The Brookes was legally entitled to carry 450 slaves under the new Bill. It had in fact sailed into Jamaica in 1782 with 649 slaves aboard; how many it set out with is not known (Williams 585-86; Fryer 480-83). Where the Plymouth 'Plan' gives an above view of a fictional slave deck of the Brookes, the 'Description' describes each deck and area of the boat where slaves might be placed. This extraordinary precision is only possible because the design obeys very closely the techniques for depicting a naval vessel as set down in late eighteenth-century naval architecture guides.

The rules of naval architecture, the precise depiction of a ship through graphic conventions so that it could be envisaged in three dimensions, 
so that it could in fact be built from a plan, were of comparatively recent invention. It was only in 1675 with the publication of Anthony Deane's Doctrine of Naval Architecture that a foolproof representational system was developed (Mansir 6-7). This book was groundbreaking:

... from Deane's time to the present, marine architects have employed a more or less standard technique for the depiction of a three-dimensional hull form on paper. The delineations include a side view called the 'sheer plan'; one-half of the top view called the 'half breadth plan'; and an end view which shows one half of each end in the same drawing called the 'body plan' (Mansir 7).

Deane's system was refined but never really superseded in the eighteenth century. ${ }^{14}$ The 'Description' obeys the basic conventions; the most radical departure lies in the presentation of two plans, or full views of the decks, from above. The conventional naval plan based on Deane's system would have shown only one half view of the upper deck. Clearly this innovation was made for dramatic impact, and yet it was not graphically eccentric. In adapting the basic structures of Deane's system to the spatial case of the slave ship, the designers of the 'Description' were close to the methods of a variety of contemporary bona fide publications of naval architexture. For example, a contemporaneous publication by Patrick Miller entitled The Elevation, Section Plan and Views of a Triple Vessel is very close in method to the 'Description.' Miller's publication consisted of a protracted commentary on a large and elaborate copperplate engraving showing two sheer draught views of the boat, one as with the 'Description' in cross section, a plan of the full upper deck, and a front-on view of the forepart and afterpart of the boat (1-10 and plate). Although no single contemporary engraving appears to have incorporated every element of the 'Description,' each drawing within it conforms to an already extant architectural model, although the only slave ships which seem to have been drawn in histories of naval architecture are Roman and Venetian slave galleys. The absence of plans of slavers from the dictionaries of naval architecture is not extraordinary. In design terms, slavers did not constitute a separate class of ship, but were usually standard trading brigs which underwent minor adaptations to carry slave cargoes once they arrived on the slave coast. ${ }^{15}$ What was shocking about the 'Description,' then, was that it adopted a style of draftsmanship used to describe the abstract beauty of ships, and then inundated those clean lines with rows of human bodies printed in black ink. The conjunction of technical engraving with the depiction of a mass of human flesh was a superb semiotic shock tactic.

From the moment of its publication the 'Description' drew compulsive and highly varied reactions from white European audiences. One 
French example demonstrates the extent to which fascination went hand in glove with a certain frustration - a frustration at being shown a plan only. In July 1789 William Clarkson travelled to Paris, on behalf of the British society for the abolition of the slave trade, where he remained for a most remarkable year. His History gives a detailed account of this period (2: 118-166). Clarkson was immediately introduced to leading statesmen and politicians in the circle of the Société des Amis des Noirs. He launched himself into the turbulent political arena of the Revolution and agitated through his contacts in the National Assembly for the immediate abolition of the French slave trade. Clarkson was keen to proselytize for the abolition cause and ordered a 'large packet' of propaganda to be sent from England. Besides coloured engravings of slave-related atrocities in Africa 'it consisted of above a thousand of the plan and section of a slave-ship with an explanation in French' (2: 151). Many of the leading figures in the Amis des Noirs are quoted as being suddenly shocked into a realization of the realities of the middle passage: they read the plan naturalistically. The Bishop of Chartres told Clarkson 'he had not given credit to all the tales which had been related of the Slave-trade, till he had seen this plate; after which there was nothing so barbarous which might not readily be believed' (2: 152-153). The Archbishop of Aix appeared to experience a revelation of disgust: 'when I first showed him the plate, [he] was so struck with Horror that he could scarcely speak' (2: 153).

Perhaps the most revealing response was that of the supreme public orator of the first phase of the French revolution, Gabriel Honoré de Raqueti Compte de Mirabeau:

... when Mirabeau first saw it ['the Description'], he was so impressed by it, that he ordered a mechanic to make a model of it in wood, at a considerable expense. This model he kept afterwards in his dining room. It was a ship in miniature about a yard long, and little wooden men and women, which were painted black to represent the slaves, were seen stowed in their proper places. (2: 153)

Mirabeau's relationship with English abolition, and with anti-slave trade propaganda, is a fascinating and neglected topic in which the 'Description' holds centre stage. Mirabeau was a founding member of the Amis des Noirs formed by Brissot in May 1788. Mirabeau was perhaps the most determined and the most courageous member of the Amis des Noirs to attempt to force the National Assembly to confront the problem of the vast French involvement in the slave trade and to force its immediate abolition. ${ }^{16}$ By March of 1790 Mirabeau had prepared what was, even by his standards, a mammoth oration upon the slave trade. The speech was to be delivered in a general debate in the National Assembly demanding 
immediate abolition of the trade. The powerful French planter lobby managed to call off the meeting and demanded a committee review on the question of the admissibility of the slave trade as a subject of open debate. The Colonial Committee subsequently effectively banned the subject by ruling that there should be no changes made to French involvement in the trade, and that anyone inciting rebellion against the planters would be guilty of treason.

Mirabeau's speech was consequently never delivered. But the answer as to why he constructed the scale model mentioned by Clarkson lies within the text of this unperformed speech. While Mirabeau was not going to argue for immediate emancipation, he was going to demand immediate abolition of the trade, and the centrepiece of his rhetoric was to be the presentation before the French National Assembly of his model of the Brookes, drawn up from the 'Description.' In doing so he was to follow a similar tack to that taken by Wilberforce, who had a miniature boat constructed according to the 'Description,' with the slave representations from the print pasted flat onto its various decks (Fig. 6). This was passed from hand to hand around the House of Commons during a slave-bill debate, but it did not violate the two-dimensional diagrammatic representation of the slaves in the original. ${ }^{17}$ Mirabeau's model was much bigger and went further in presenting the slaves in three dimensions. The model was to be produced in front of the National Assembly while Mirabeau read out a remarkable meditation upon the middle passage. This is perhaps the most developed attempt by an abolitionist to imagine what it was like to be confined on a slave deck, and it is ultimately a meditation upon the 'Description,' an impassioned attempt to bring the engraving to life. The text of Mirabeau's speech implies that he was suddenly going to reveal his model to the Assembly, much in the manner of a piece of shocking and hitherto undisclosed court evidence. The sight of the ship was then to be followed up by an extended meditation upon its implications:

Behold the model of as vessel laden with these unfortunate beings, and seek not to turn away your gaze! How they are piled one upon the other! How they are crammed into the between-decks! unable to stand erect: nay, even seated, their heads are bowed. More than that, they cannot move their members, tightly bound, nor even their bodies; for, partakers of all the wants, of all the miseries of him who shares their irons, each man is attached to another: often to a dying one, often to a dead body! Mark how the vessel when it rolls hurts them, mutilates them, bruises them against each other, tears them with their own chains, and presents thus a thousand tortures in a single picture! They crouch themselves down; all the space is filled; and the insensate cupidity which should succour them has not even foreseen that no room for passage remains, but that 
it is necessary to tread under foot the bodies of the living victims. Have they at the least a sufficent quantity of wholesome air? Let us calculate it together. A space of a little less than six feet in length, and a little more than a foot in breadth, is the base of the column of air, the smallest possible, which has to suffice for the respiration of each one ... The poor wretches! I see them, I hear them gasping for breath: their parched and protruded tongues paint their anguish, and cannot further express it! How they hang to, how they cluster round, the grates! How they endeavour to catch even rays of light, in the vain hope of cooling themselves thereby, were it only for an instant!

Listen to those groans - behold the last efforts of these wretches, who feel themselves suffocating - then all is silence! That air meted out by barbarity, that air impregnated with grief, with despair, and with blood, is nothing better than a homicidal atmosphere of pestilential vapours; and despite your efforts, room is only given to the victims by the death of half the captives. (Smith 2: 150-152)

Had he ever been able to make this performance, Mirabeau would have achieved a complete descriptive anithesis to the 'Description.' One explanation of Mirabeau's fusion of psychological realism with the abstract detachment of the 'Description' relates to the mesmeric formal properties of the print. There is an awful rigour about the design; people are reduced not so much to signs of what was/is human as to elements of decoration. The abstract configurations of white and black, of positive and negative space, are most satisfying in their repetitive variety. In purely aesthetic terms the slaves have no human presence at all; in terms of compositional balance the white spaces where the slaves are not are as important as the black spaces of ink which represent their bodies. Is it possible that it was precisely this formality, which appears to deny the flesh and blood presence of the slaves, which led Mirabeau to seek the design's realization in three dimensions and then to try to imagine himself a slave in the hold? In a sense he was trying to humanize the 'Description,' to give the victims a voice. Again, however, despite the elaborate and impassioned nature of Mirabeau's expression of empathy, the slave is culturally void. Mirabeau's emotions of outrage and pity are a test; he tests his - and his audience's - moral and intellectual capacity for imagining suffering through subjective projection onto the site of the slave bodies, but the rules for the test are ultimately laid out by the 'Description.' They are rules which allow the black body no voice which is not the creation of a white observer.

Mirabeau's response is an extreme example of the effect of the 'Description' as a plan, as an instruction to construct, but I would also argue that the power of the work grows out of the way it fuses two other elements, one narrative, the other formal. The 'Description' was, as we have seen, drawn according to the conventions of a relatively new style 
of naval diagrammatics, involving description through precise crosssections and projected views. But as a boat packed with living things sailing on the ocean for a set period it is embedded in Judaeo-Christian narrative and myth. Mirabeau's conversion of the 'Description' into a model boat suggests a correlation between the slave ship and the Ark. Even in the eighteenth century, the boat taking the first mythic journey stowed with all there was of life on this earth was a familiar plaything. Noah's ark, the first boat, provided not only a mythic base but also a narrative and graphic method for the abolitionists.

In the mid-seventeenth century John Wilkins, Bishop of Chester, included a lengthy digression on Noah's Ark in his 1668 Essay towards a real character, and a philosophical language. This discourse addresses what was, even then, a theological old chestnut: was Noah's Ark big enough to hold all the animals in the world? To answer the objections of 'some heretics of old, and some Atheistical scoffers in these later times' Wilkins adopts the same procedure to prove his case as the abolitionists would later adopt to give a 'real' account of how many slaves would be put on a slave ship. He cites the precise dimensions of the ark as given by Moses in Genesis 6:15; he then provides a table of all the varieties of animal, categorized according to foodstuff, and an estimate of 'what kind of room may be allotted to the making of sufficent stalls for their reception' (164). With this information he then produces his 'Diagram' (Fig. 7), an external view of the entire coffin-like structure and a three-quarter section of the ark, stocked with its living freight, the dimensions and positioning of the different decks indicated by lettering.

There are strong similarities with the 'Description': in both cases the boat designs grow out of a set of printed instructions, a series of measurements, and the design constitutes a pictorial realization of the plan. The delight in providing a programmatic explanation of the technical construction of the ark was not limited to the seventeenth century but was carried through and refined in the eighteenth; indeed, increasingly refined versions were being produced right up to the publication of the 'Description.' The first edition of the Encyclopaedia Britannica in 1773 carried a half-page plate of the ark. The text draws heavily on Wilkins's arguments, and the plate, although more naturalistic than Wilkins's and set in a seascape, appears to have evolved out of Wilkins's basic design (Britannica 1: plate opposite 425).

The publication of the Encyclopédie, one of the summarizing moments of the Enlightenment in terms of the display of knowledge through text, both in words and images, also took in the plan of the ark. The elaborate plate describing the ark first appeared in the 1777 supplementary volume of plates (Fig. 8). The main design for the ark was directly copied from a French translation of the first edition of the Encyclopaedia Britan- 
$n i c a^{18}$ (Fig. 9). The scenic presentation of the whole boat is accompanied, however, by a series of details giving projected views of sections of the ark. There are cross sections and three-dimensional spatial projections of the probable layout of individual stalls. The plan was accompanied by precise technical instructions on the construction of the stalls for the animals, right down to how the dung was to be collected and removed. ${ }^{19}$ With the Encyclopédie's engraving of the Ark one arrives at a late eighteenth-century treatment which in its utilization of contemporary styles of technical drawing, and its concern with practical detail, parallels the style and thought of the 'Description' of the slave ship. The 'Description,' to be printed barely a decade later, exhibited a similar concern for the precise number and spatial disposition of the slaves, and beyond this of the ship's ropes, and even of the 'poo poo tubs' on the slave decks.

Yet one aspect of the power of the 'Description' comes not from its similarity to the plans of the Ark, but from its essential difference. While all these designs share a stylistic similarity, and while they describe a problem of packing a boat with livestock, the comparison also stresses that the slave ship is a precise parody of the ark; to use a term of Jean Baudrillard's, it constitutes an 'anti-ark. ${ }^{20}$ The vision of harmony afloat, and of an infinitely extended familial order with all creation linked two by two, is torn into disorder. The slave ship as anti-ark embodies a series of balanced antitheses to the ark: greed is substituted for love, fear for trust, repetition for variation, and sameness for difference. The cargoes of the two boats are perfectly antithetical. The ark emphasized the unique value of each created thing, and each life form aboard is simply unique; the slave ship emphasizes the homogeneity of the slave cargo, and each life form aboard is, in its legal status, the same.

The 'Description' tells us of a white fascination with its ignorance about a terrible black (and white) experience. For all its familiarity I would say that it finally emphasizes the indescribable nature of the experience of the middle passage, and that may be what makes it ultimately an appropriate memorial. The 'Description' is not a record of black slave experience, for such experience is unrecoverable in several ways: first, in the sense that it should not and could not, decently, be re-invented; second, in the sense that the experience of each individual on the middle passage was unique and unrepeatable; and finally, in the sense that none of us, black or white, should ever consider him/herself to have recovered from this experience. The 'Description' is perhaps best understood as a memorial to a disaster, not as a representation of what ever happened. As a memorial it acts as a point of focus for collective historical memory, as a space for meditation, as something clear and clean which paradoxically, as the Meynell drawing insists, has no right to be so. The economic and legal basis of the English slave trade was 
cleanly defined and functional. The trade itself as a day-to-day reality on ships was arbitrary, filthy, and chaotic, but something which no facts can adequately describe.

The question of how to read the 'Description' is even more complicated for audiences today because the accreted history of the image which we have inherited is not stable. The 'Description' is a protean entity which from the moment of its publication appeared in an enormous number of popular mutations. The mutation continues to occur and this paper will conclude with a brief overview of the processes of transformation. It is probably impossible to construct a complete account of the multiple adaptations and reprintings of the original engraving in England, let alone in Europe, and North and South America. Many versions were produced in ephemeral forms such as handbills, broadsides, and children's books, and must have perished, but some of the most significant surviving translations can be considered as indicators of what, in the course of two hundred years, the 'Description' has come to mean.

As we have seen, the image was widely disseminated in France in the year of its first printing. Like the SEAST's 'Seal' it was also printed in North America almost as soon as it came out. As early as May 1789 the magazine American Museum had brought out a version, which was then readapted from this source almost verbatim by the Pennsylvania Society for the Abolition of the Slave Trade. This edition, printed by the Philadelphia printer Mathew Carey, in a very big edition of 2,500, gave the image general currency in the North American free states. ${ }^{21}$ Yet the relationship of both versions to what one might term the classic image, printed by the London Committee, is complicated. The Philadelphia version is stated to be based upon an English pamphlet by the Plymouth Committee, and it is clearly adapted from the original single sheet engraving produced by the Plymouth Committee of the SEAST in December 1788. Both American versions repeat the simplifications of the original Plymouth 'Plan.' All the slaves except four are standing vertically, and the title inscription has been exactly reproduced. The American versions have, however, anticipated the later London version in excising the kneeling slave from the abolition seal.

It was this awkward 'Plan' that went on to serve as the basis for many adaptations which reappeared in illustrated pamphlets in North America over the next decade. The 1807 edition of Thomas Branagan's abolition poem The Penitential Tyrant has a version of the engraving and of the Philadelphia broadside text. This was probably inserted at the instigation of Branagan's printer Samuel Wood, who reprinted the same text and engraving in his own abolition compilation The Mirror of Misery; or, Tyranny Exposed, which was also printed in New York in 1807. In 1808, 
however, the more sophisticated London Committee 'Description' was reprinted in Thomas Clarkson's History, which came out in a Philadelphia edition also in 1808 (2:112). After this date the majority of American publications which reproduce the slave ship diagram appear to use the version reproduced in Clarkson's History. For example, the large foldout wood engraving in Richard Drake's Revelations of a Slave Smuggler of 1857 is reproduced from an edition of Clarkson. ${ }^{22}$

The American adaptations indicate both the speed with which versions of the 'Description' were subsumed into East coast print culture, and the longevity of the image. It is also striking that the American versions are remarkably true to their English models. Such adaptive conservatism was not the case in England, where the image underwent a series of bizarre reincarnations, some so extreme that the original content exists only on the margins of legibility. In 1827 the image appeared in Scenes in Africa for the Amusement and Instruction of Little Tarry at Home Travellers. Here the middle passage was summarized in one succinct paragraph:

The captain of a slave ship wishes to carry as many as he can at once; the hold of his vessel is therefore measured and only sixteen inches each, in width, are allowed for the men, and less for the women and children. There they lie, so close, that it is impossible to walk among them, without treading upon them. They have no more room than a man has in his coffin; you may see by the plan of the slave ship how they lie. Numbers die almost every night from such close confinement, and the suffocating air it breeds. Nearly half the number have died in the passage. (Taylor 63)

The accompanying engraving, little bigger than a postage stamp, represents the slave bodies as a series of thin attenuated rectangels with no human form or feature. In this version the reduction of the human form to a space allocation is complete. The slaves have literally disappeared as a human representation.

Throughout the nineteenth and twentieth centuries the image continued to appear in a vast array of published materials relating to the history of slavery. It graces a host of abolition publications of the 1850s, including John Cassell's 1852 Uncle Tom's Cabin Almanack, which also included a cross-section of an African canoe packed with slaves being transported from the coast to the main slave ship. ${ }^{23}$ In the context of maritime architexture, undoubtedly the most extreme adaptation is a full-page plate in Captain G. L. Sulivan's 1875 Dhow Chasing in Zanzibar Waters (Fig. 10; plate opposite Sulivan 114). The plate shows a cross-section of a Dhow captured by a Royal Navy patrol illustrating the mode of smuggling slaves: '. . . the poor creatures are stowed sometimes in two, 
sometimes in three tiers on extemporised bamboo decks, not sufficiently distant from each other to allow them to sit upright' (114). The slaves are still imprisoned within the impersonality demanded by the conventions of the 'Description'; they form an almost completely indecipherable block of ink.

Over the past three decades the multiple reproduction and adaptation of the 'Description'has taken spectacular forms in popular publishing. It has a promiscuous appeal for blacks and whites, for musicians and jewellers, for writers of popular history and elevated literary art. Some of these adaptations attempt to reduce the diagrammatic objectivity of the original, while others exaggerate this quality. Perhaps what they all finally testify to is an uncertainty about the adequacy of the original design as a testimony to the middle passage.

A radically reconstructed version of the 'Description' forms the central device for Bob Marley's 1979 album Survival (Fig. 11). The central section of the slave ship, reprinted three times and turned into a rectangular strip, dominates the album cover, where it stands out in black and white. The word 'SURVIVAL' in white is stencilled over the design, obliterating some of the slave bodies in a message of pan-Africanist optimism. The rest of the cover is made of a dancing coloured mosaic of all the flags of the post-imperialist African nations. On the record sleeve the image is printed again, in black and white, over the lyrics. For Marley and his designer, the image has been rebuilt into a message of hope for contemporary Africa, and provides a reading of the 'Description' which is in line with Gates's demand that we must not see the middle passage simply in terms of the destruction of African culture and life.

The 'Description' has been taken up in other politically-charged publishing contexts. A recent hard-hitting 'beginners' guide' to the history of the Atlantic slave trade, The Black Holocaust for Beginners, includes a pen and ink reworking of one of the cross-sections shown in the 'Description,' which sits odddly among the otherwise emotionally volatile and realistic imagery (Anderson 82). At the back of the volume there is an advertisement for a miniature cast of the 'Description' as a piece of jewellery with conch shells attached on springs. This photograph is accompanied by the advertising copy: 'If you desire a gold, silver or brass pin depicting the Slave ship 'Brookes' . . . contact Who Deserves it More Than You?' (Anderson 167). This example strangely duplicates the process by which the abolition 'Seal' devolved into a piece of jewellery in the 1790s. At this point it has to be asked whether the 'Description' has not moved into a strange semiotic hinterland where it functions more as a fashion accessory than as a piece of political propaganda.

The 'Description' has been deployed in a mass of other publishing contexts. The abstract beauty of the design made it desirable as decora- 
tive endpaper for numerous publications on slavery, such as James Pope Hennesy's Sins of the Fathers (1963), or Terence Brady's The Fight Against Slavery (1975). ${ }^{24}$ The most elaborate deployment occurred recently when the print was used in a variety of ways inside and outside Barry Unsworth's slave trade blockbuster Sacred Hunger, which won the Booker Prize in 1992. The mass marketing glut which ensued equipped the hardback edition with a dust cover which consisted of three small groups of the slaves from the famous 'Description' repeated over and over on a tea-coloured background (Fig. 12). Large blowups of this cover, in placard form, also decorated the display windows of the big booksellers in the weeks following the prize announcement. The end-papers of the book reproduce the design twice in a tasteful combination of greys. Inside the book a section of four manacled slaves has been cut out, and used as a little printer's flourish to adorn each chapter's title page. Yet the design was not considered appropriate for the merchandizing of the paperback edition several months later. This, at least in its English manifestation, carried a garish soft-focus pastel protrait of two piraticallooking young black men. One might speculate on the reaons behind the jettisoning of the 'Description' at this stage. ${ }^{25}$

This brief excursion into the history of the popular absorption of the 'Description' demonstrates the lasting impact of the work, but leaves open the question of how adequate the image finally is as a response to the memory of the slave trade. Publishers, record sleeve designers, and jewellers insist on dismembering the original and reconstituting it. In the end, each reapplication must be taken on its own terms. Such cultural remanufacturing can paradoxically be both politically responsible and commercially opportunistic, as with the Survival album cover, or can come dangerously close to exploitation, as with the marketing of Sacred Hunger. As we have seen from the cases of the models made by Wilberforce and Mirabeau, the idea that the 'Description' could be improved upon through adaptation into three dimensions is not a new one. Perhaps all one can say at this stage is that, for better or worse, this image is as close as the abolition movement in Britain got to the creation of a final monument to the middle passage. For Western culture it appears to retain this status.

MARCUS WOOD

University of Sussex 


\section{DESCRIPTION OF A SLAVE SHIP.}
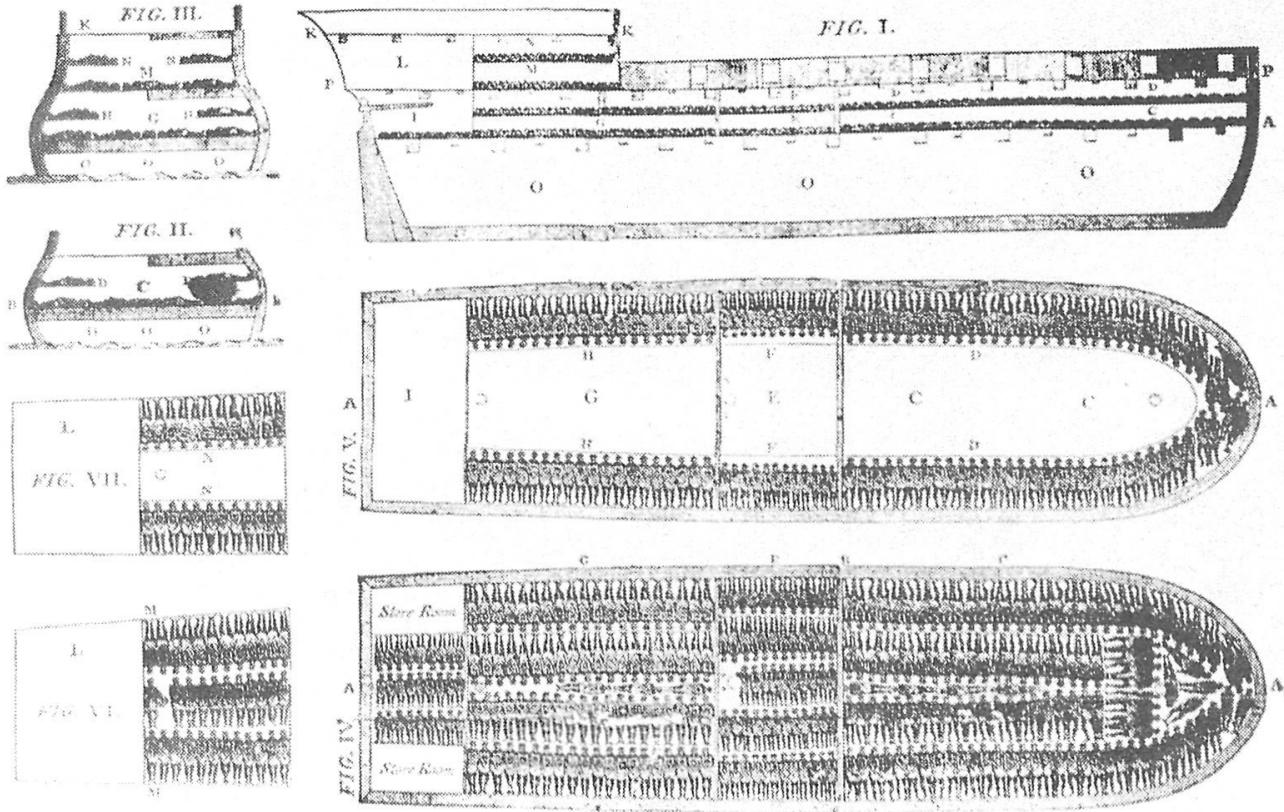

Fig. 1. April 1789. Description of a Slave Ship. Engraving on copper. Published by the Society for Effecting the Abolition of 


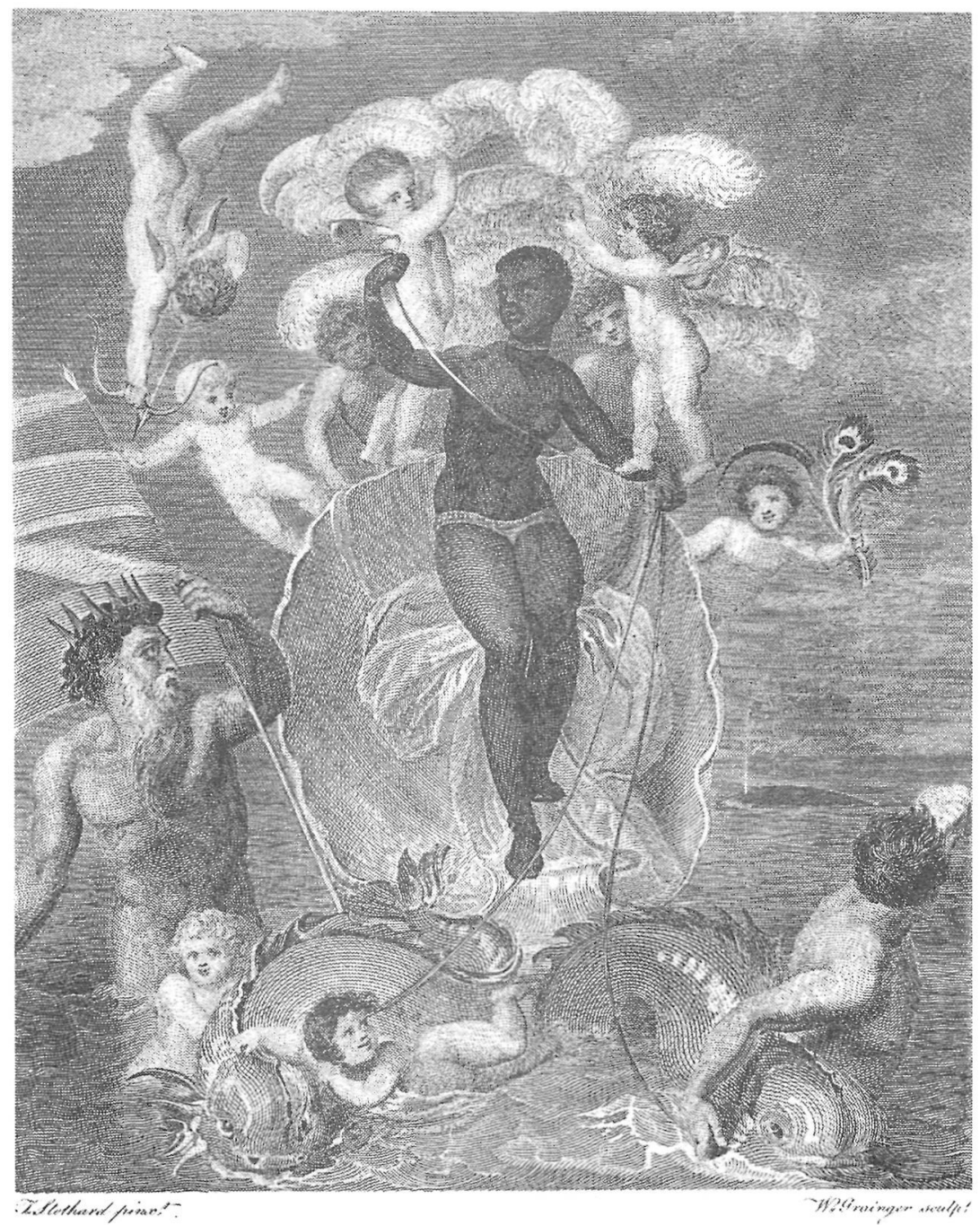

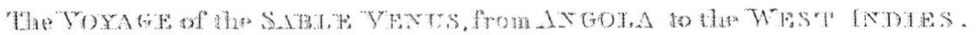

Fig. 2. 1793. The Voyage of the Sable Venus, from Angola to the West Indies. Engraving on copper. Reproduced from supplement to Bryan Edwards, The History, Civil and Commercual of the British West Indies. Bodleian Library, Oxford. 


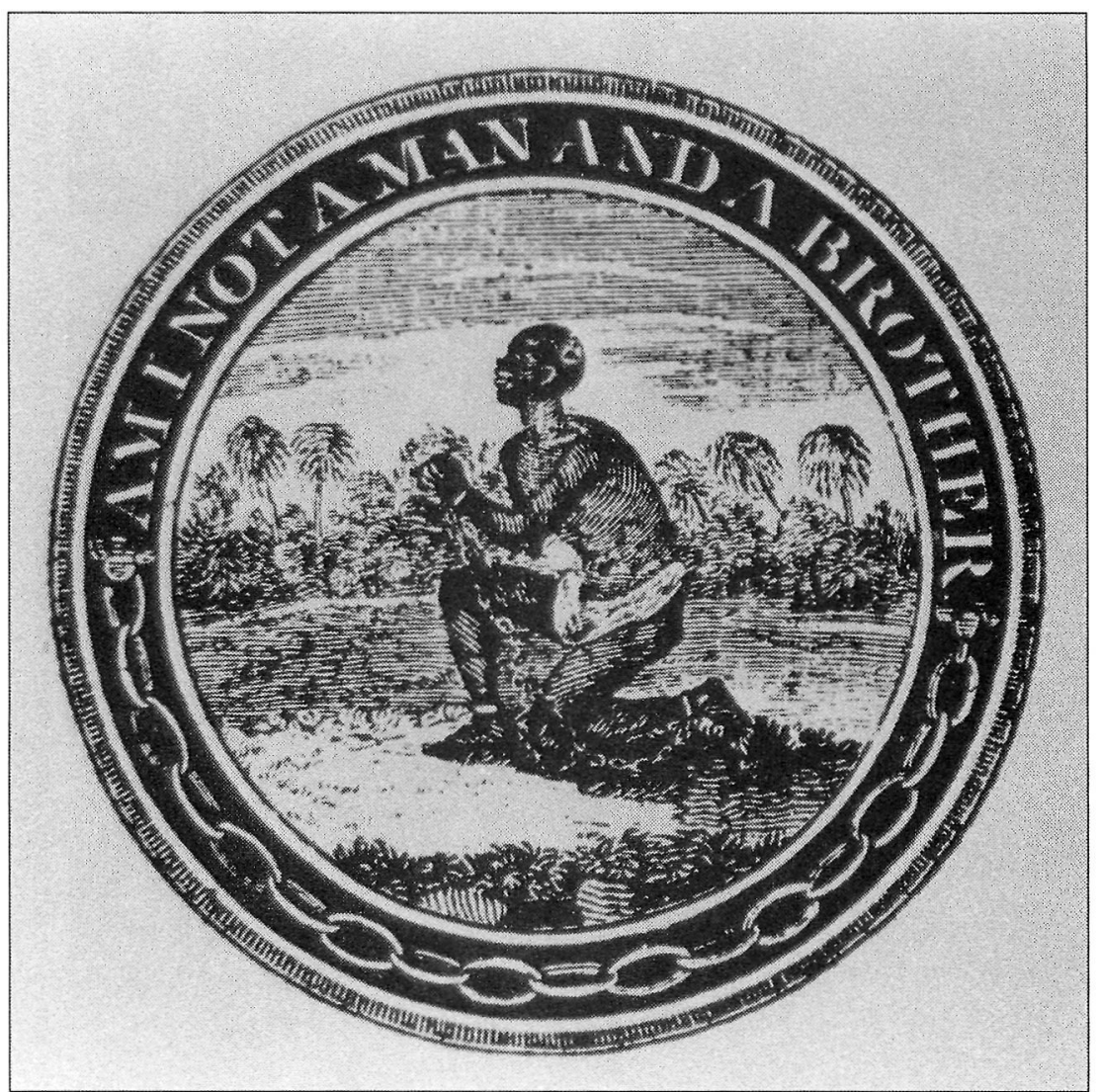

Fig. 3. 1788. Abolition Seal. 'Am I Not a Man and a Brother.' Woodcut. Society for Effecting the Abolition of the Slave Trade. Bodleian Library, Oxford. 


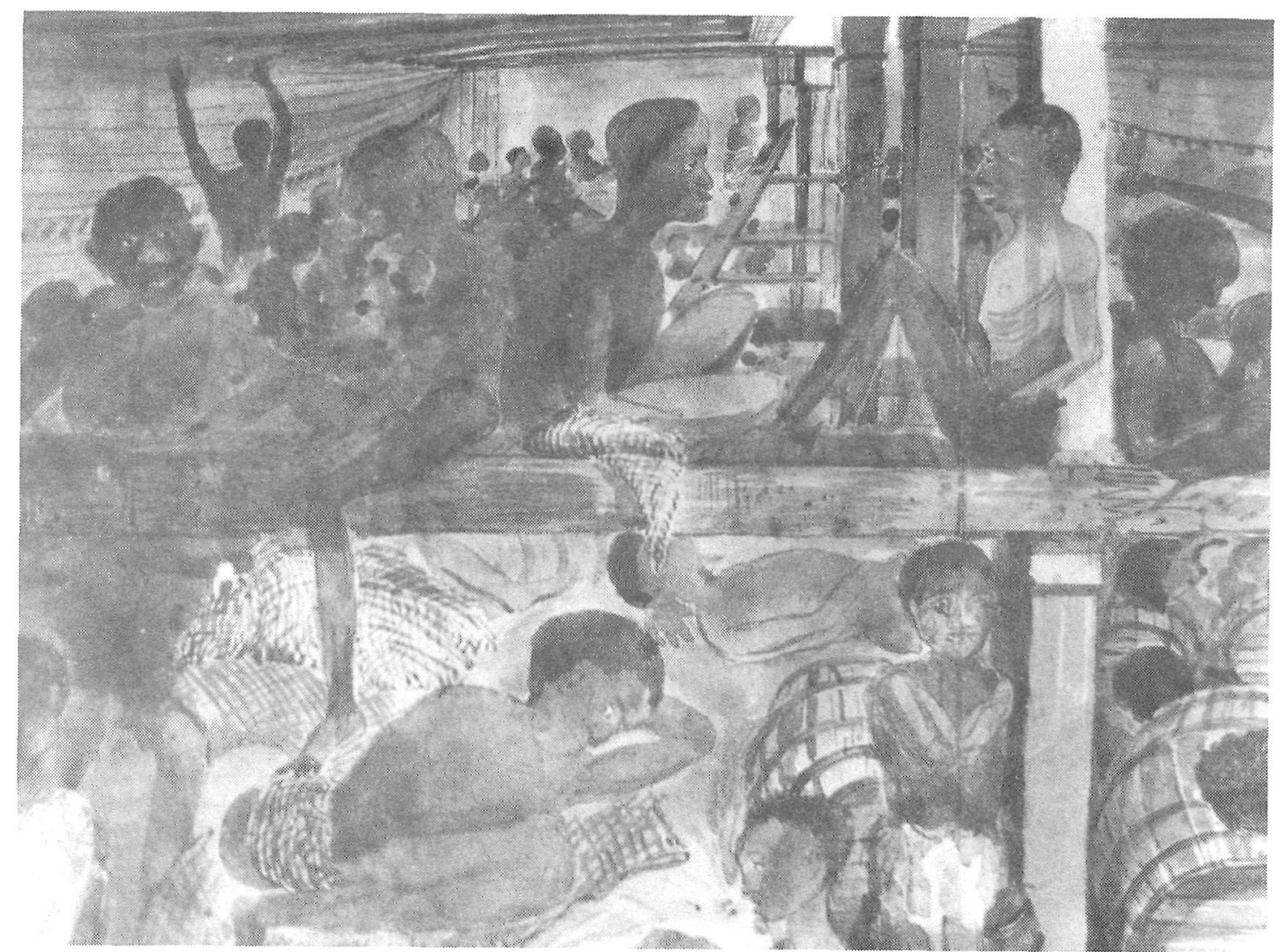

Fiz. 4. 1846. View of the Deck of the Slave Ship Albanoz. Detail. Water colour drawing. Lieutenant Godfrey Meynell. National Maritime Museum, Greenwich. 


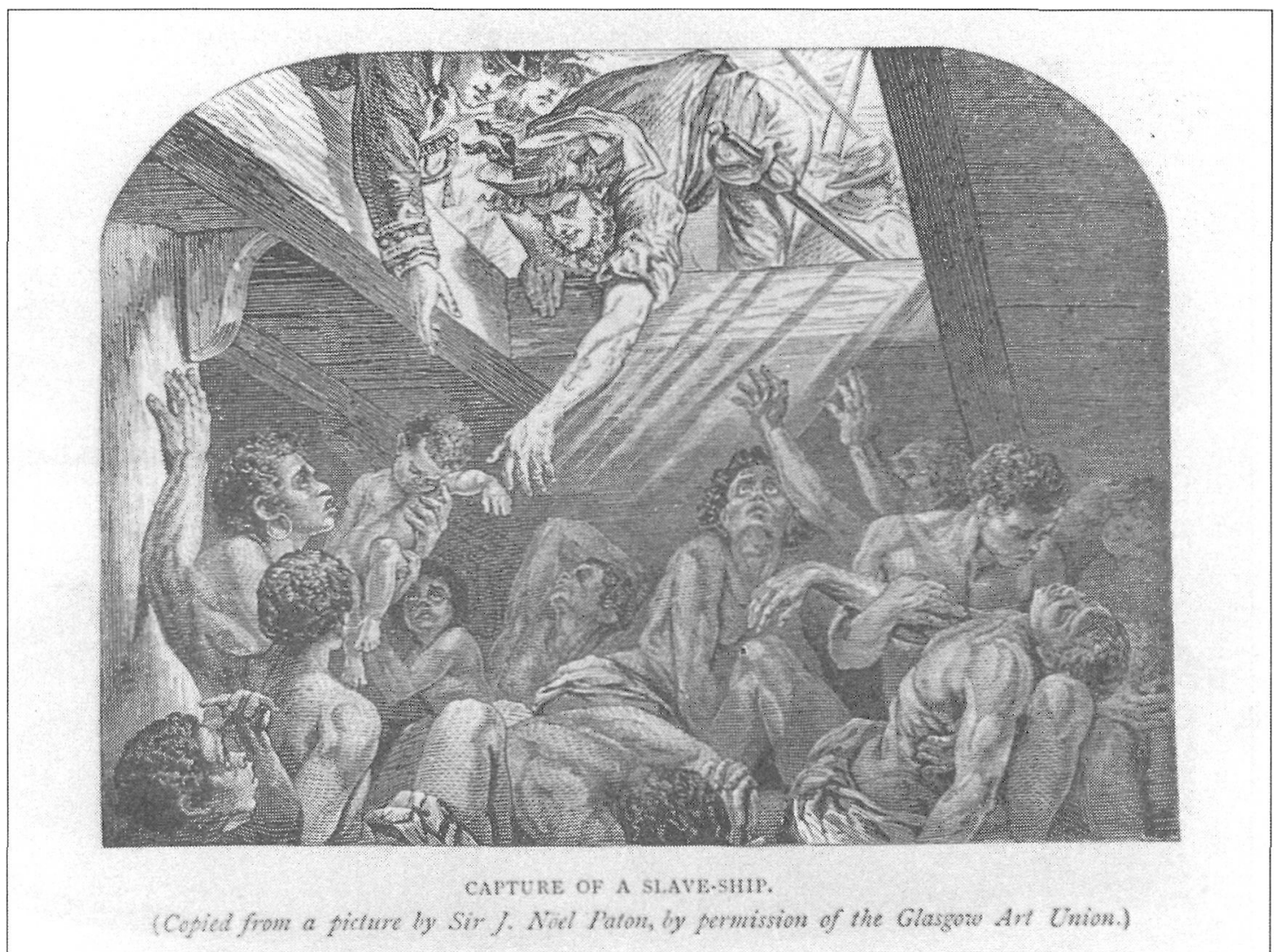

Fig. 5. 1915. Capture of the Slave Ship. Woodcut. Reproduced from Charles D. Michael, The Slave and His Companions. 


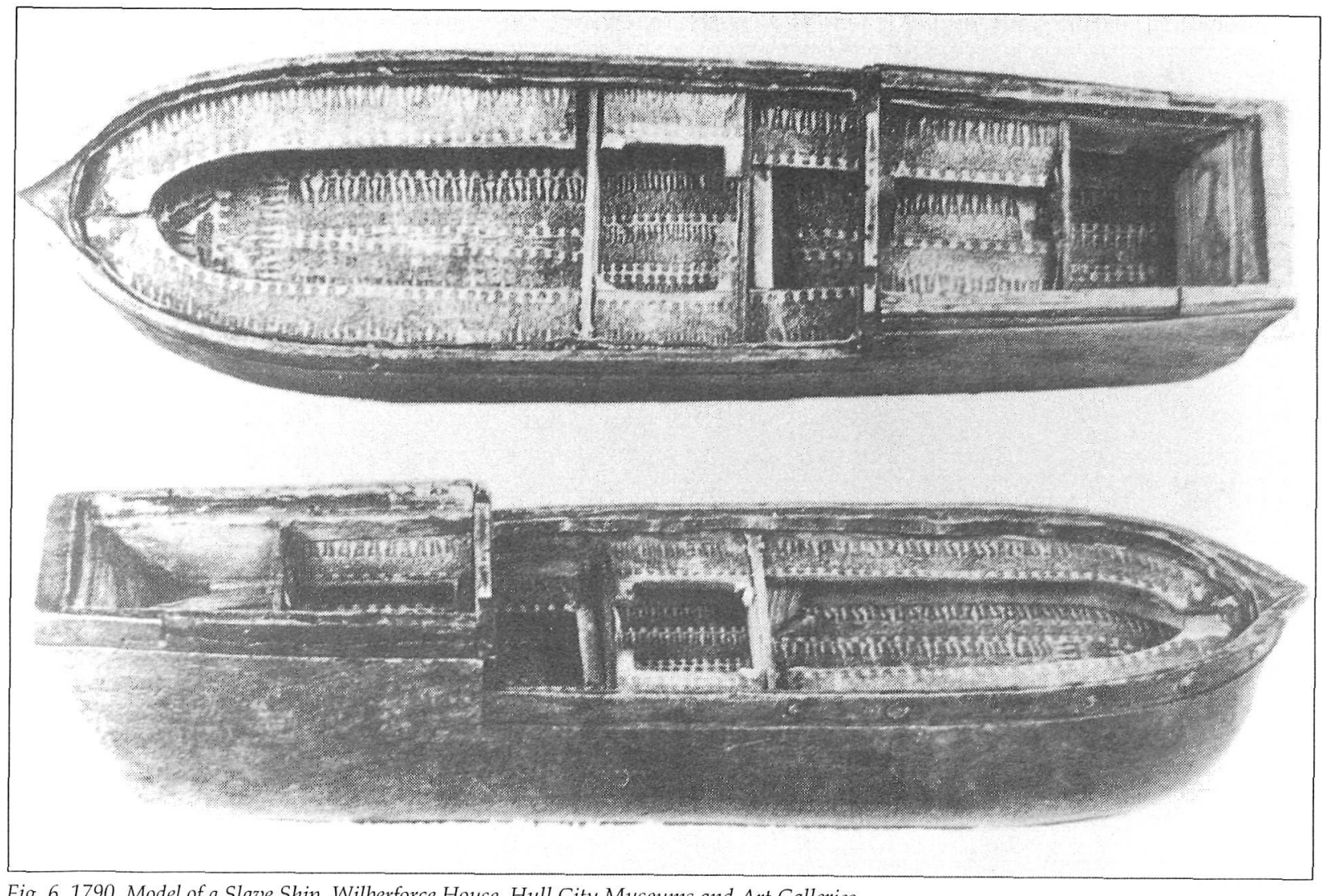




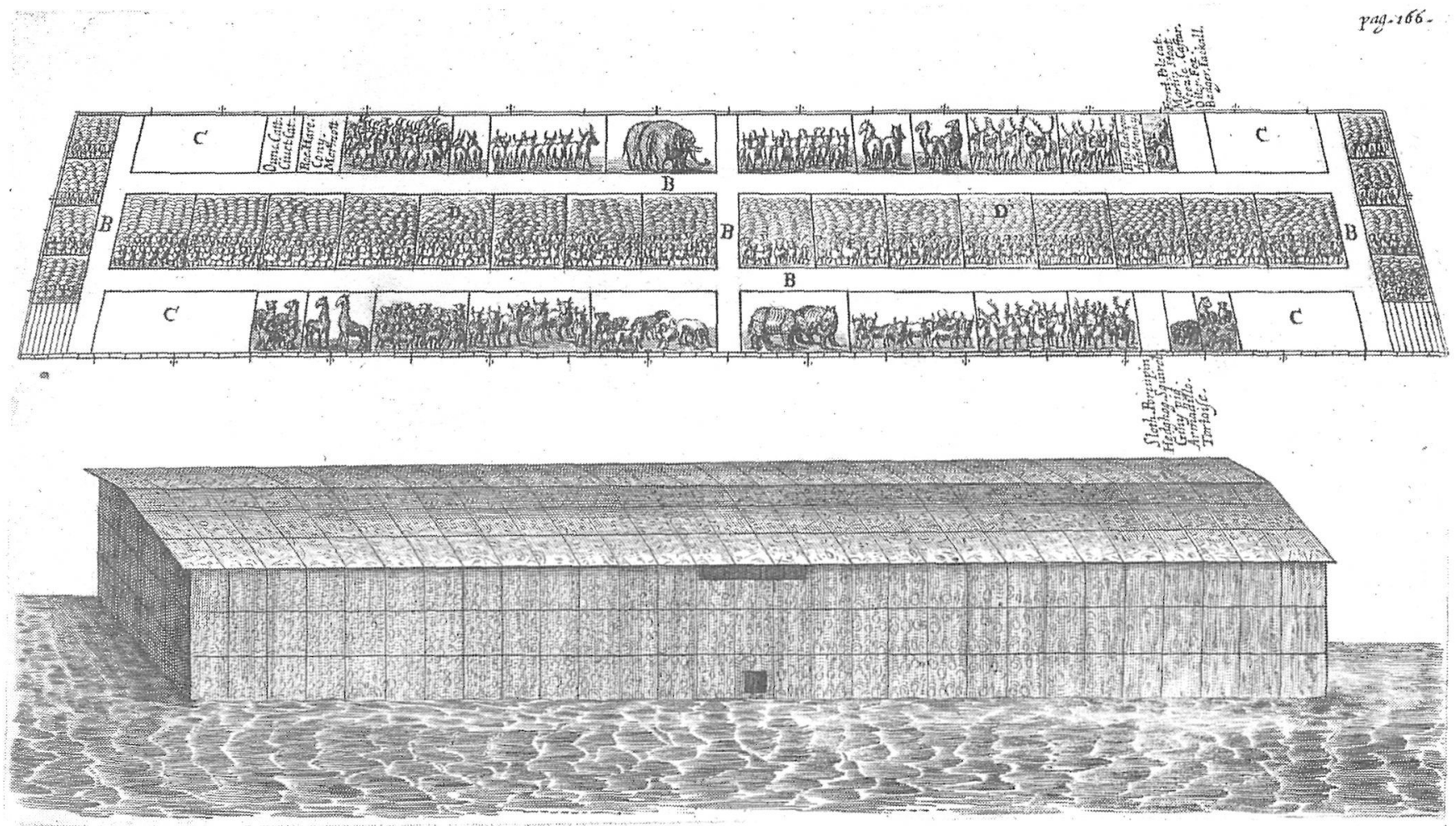

Fig. 7. 1668. Plan of Noah's Ark. Copper engraving. From John Wilkins, An essay towards a real character, and a philosophical language. Bodleian Library, Oxford. 


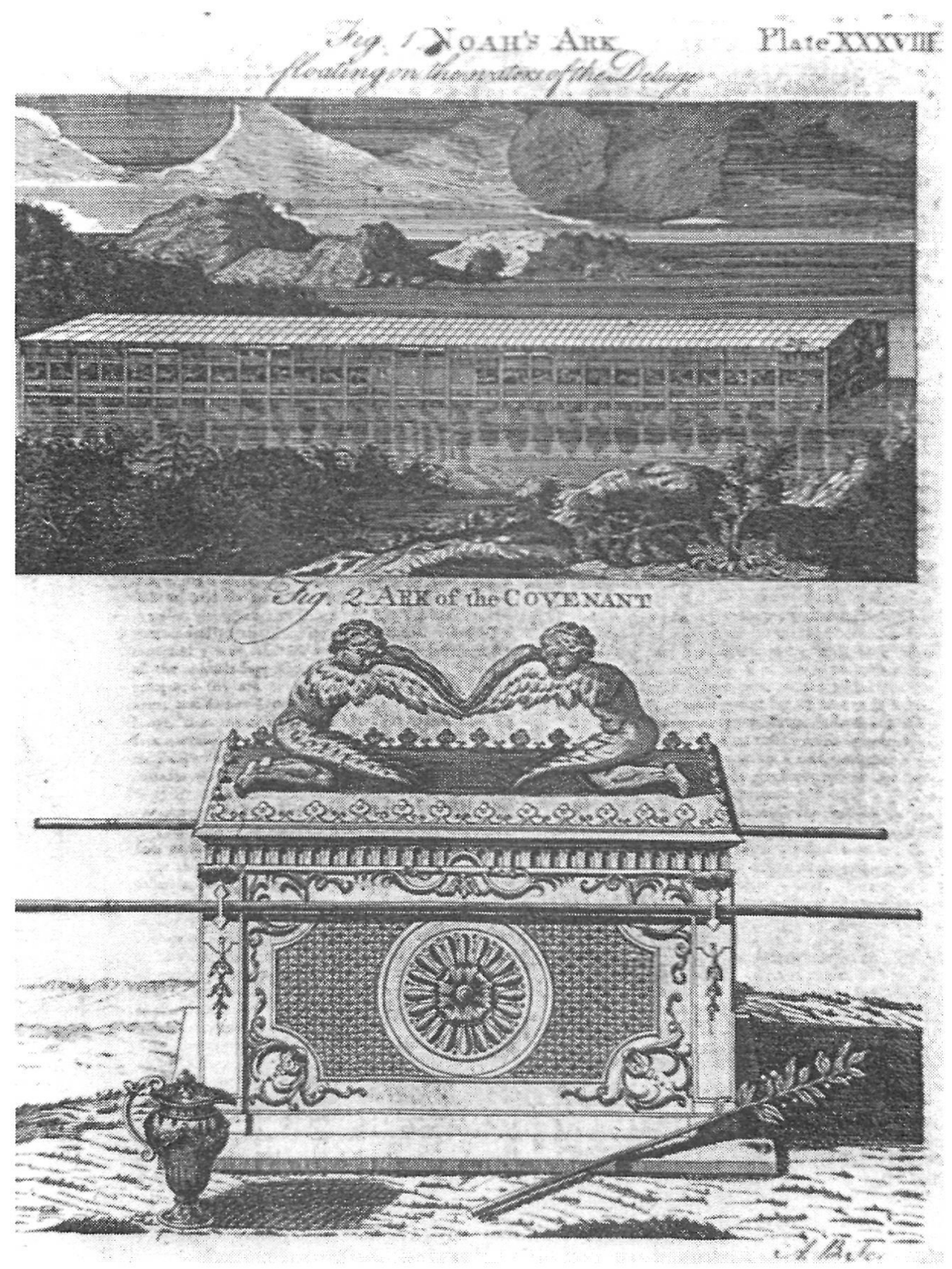

Fig. 8. 1773. Noah's Ark, from Encyclopaedia Britannica. Copper engaving.

Bodleian Library, Oxford. 


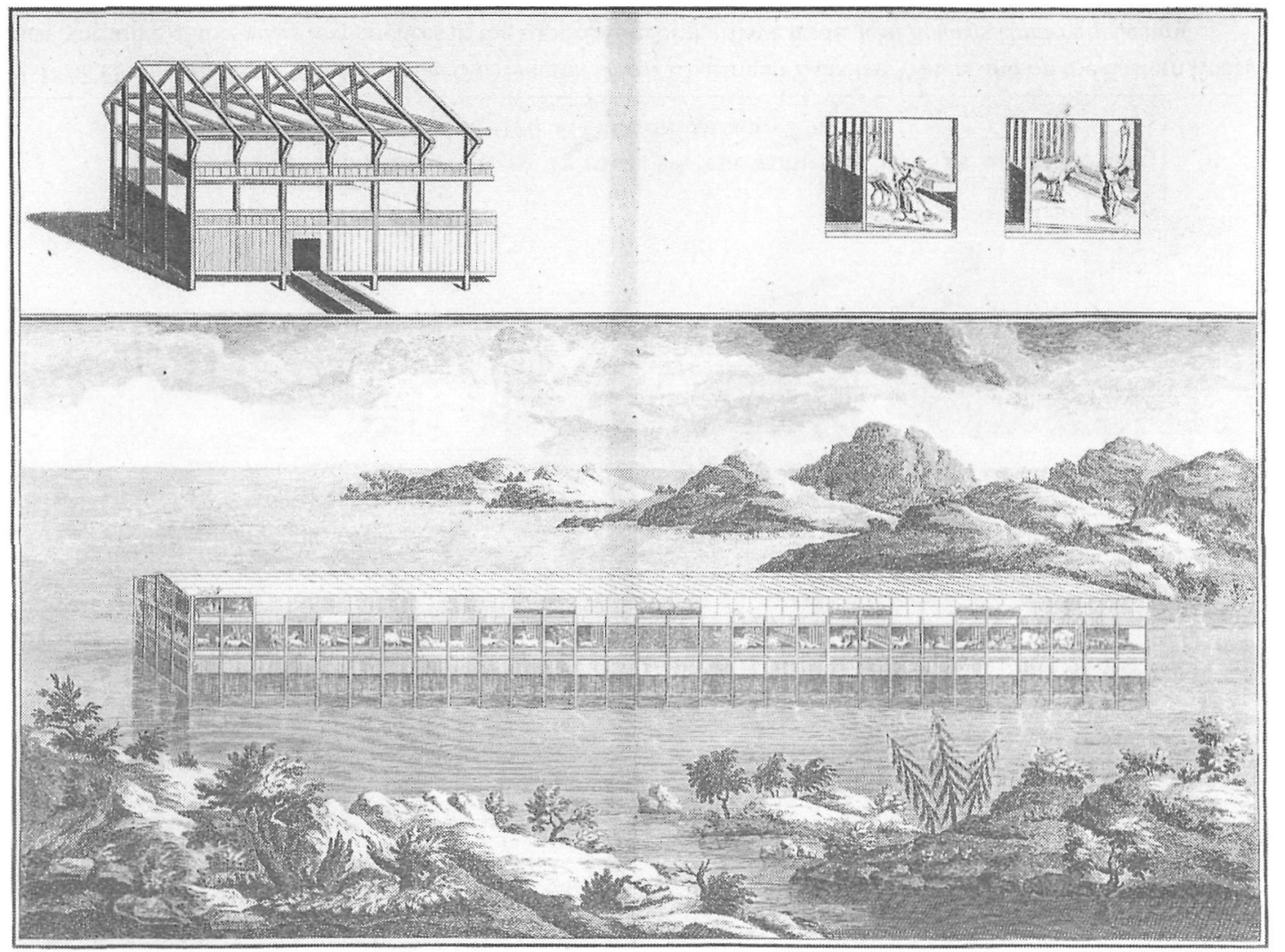

Fig. 9. 1776. Arche de Noë, from Supplément à l'Encyclopédie, ou Dictionnaire Raisonnée des Sciences, des Artes et des Metiers. Copper engraving. Bodleian Library, Oxford. 


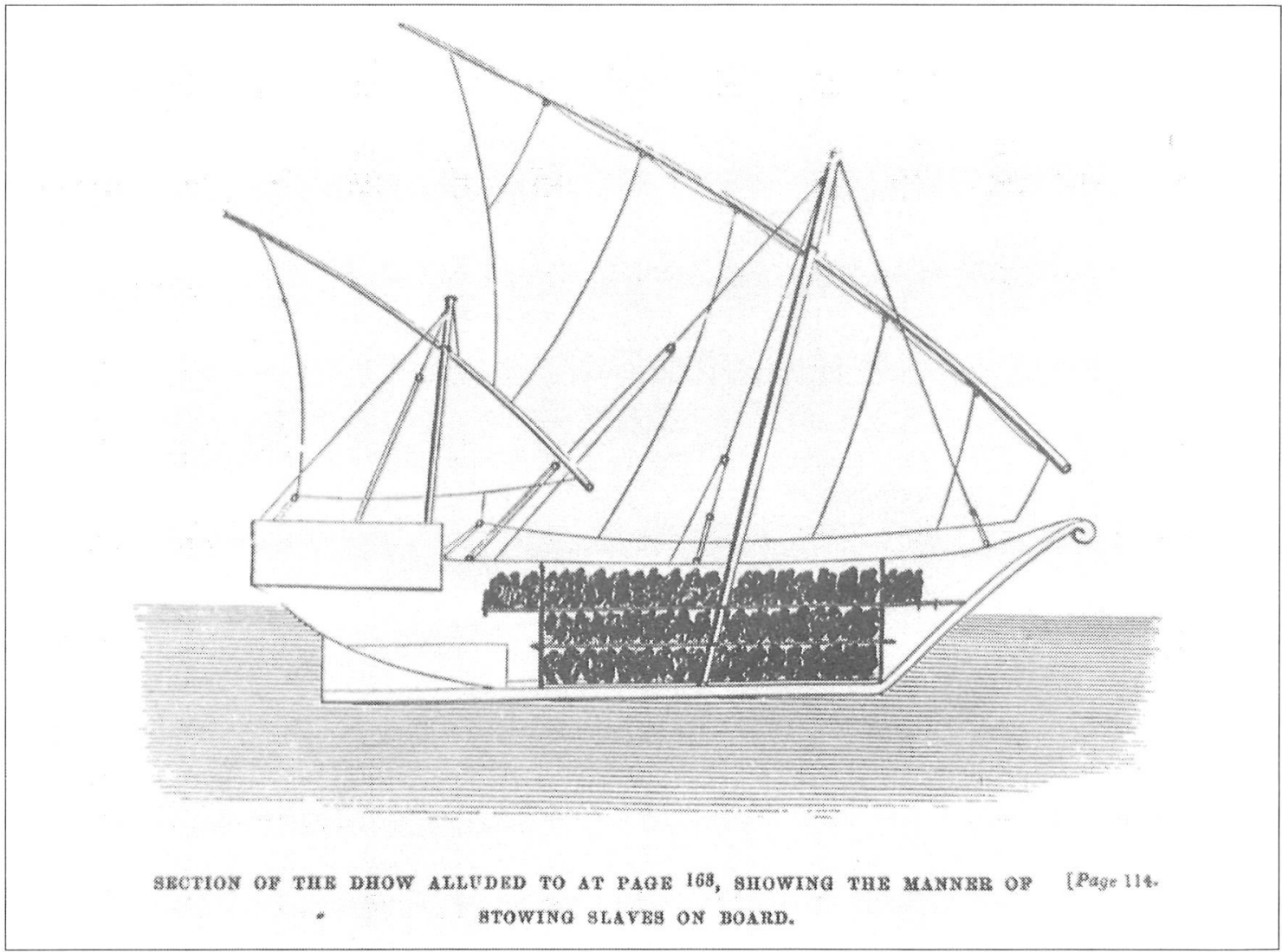

Fig. 10. 1875. Dhow with slaves. Woodcut. From G.L. Sulivan, Dhow Chasing in Zanzibar Waters and on the Eastern Coast of Africa Narrative of five years' experiences in the suppression of the slave trade. John Rylands University Library, Manchester. 


\section{BOE MARLEY \& THE WATLERS}

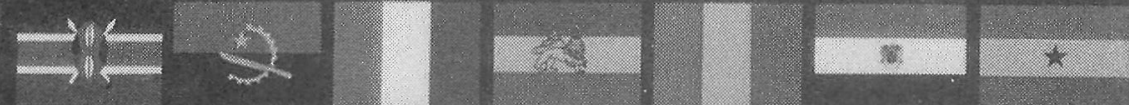

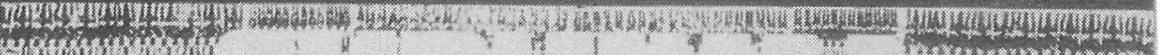

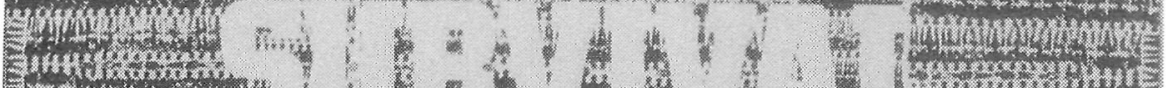

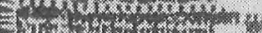

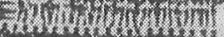

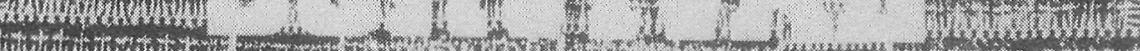

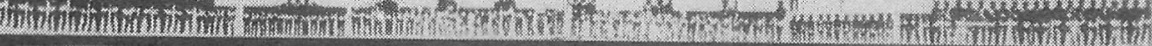
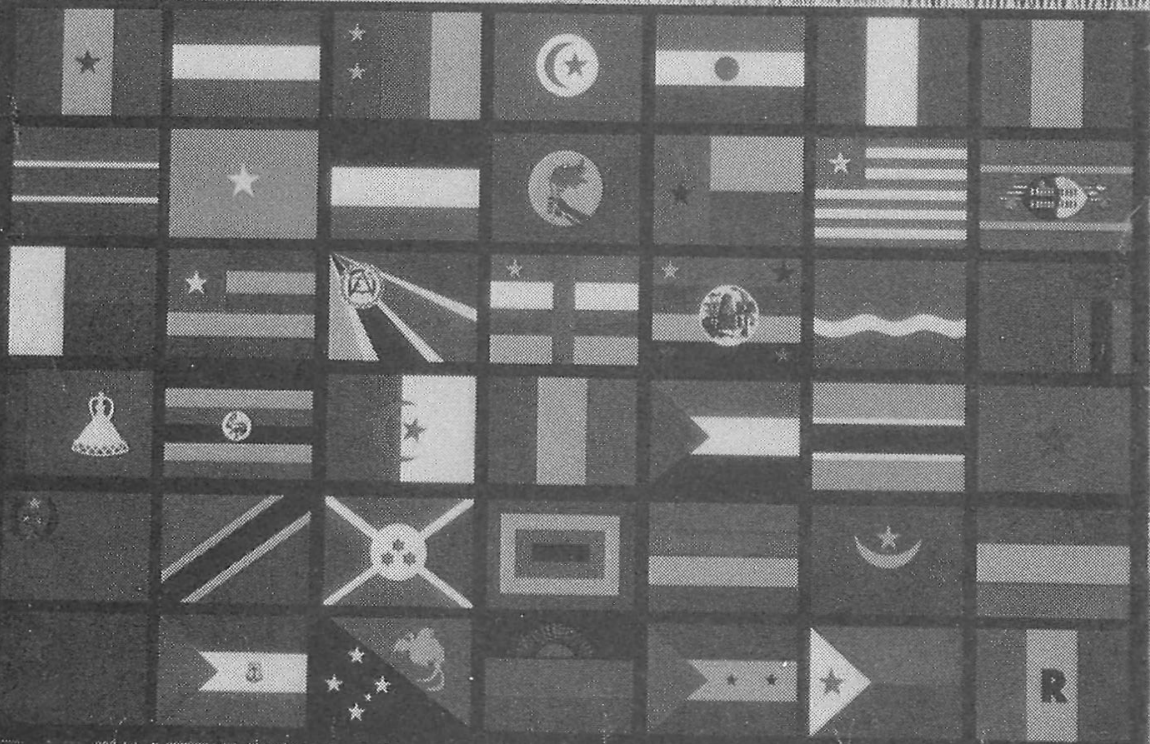

8

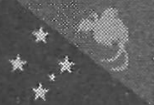

:

Fig. 11. 1979. Survival. LP album cover and record sleeve. Island Records, 1979.

(Author's collection) 


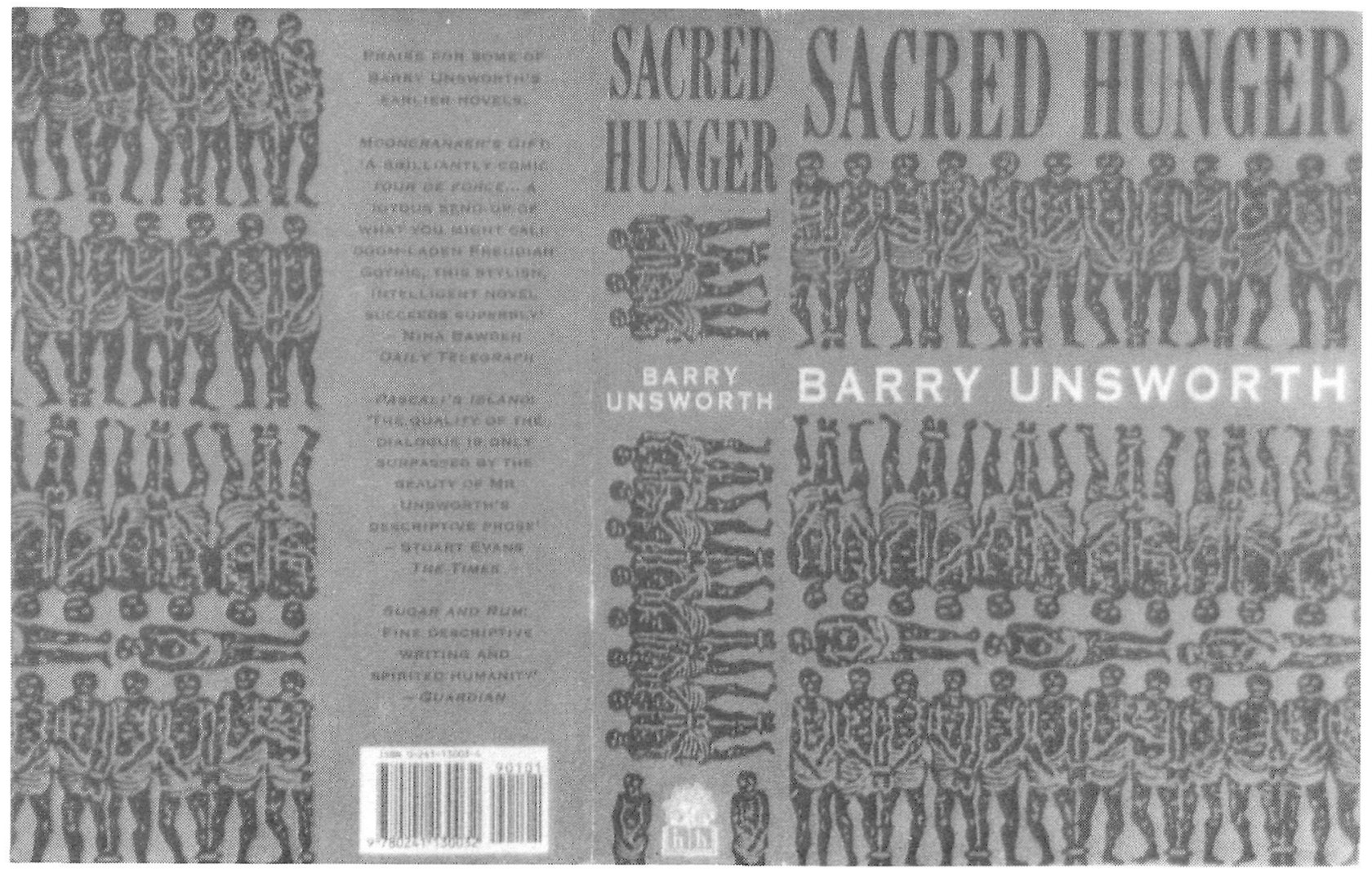

全

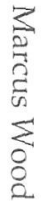

Fig. 12. 1992. Barry Unsworth, Sacred Hunger, dust jacket. (Author's collection) 


\section{Notes}

1 There are several fine studies which analyze the economics and historiography of the Atlantic slave trade and its position in the abolition debate. For a powerful modern Marxist analysis see Blackburn 293-331. The most succinct economic summaries are in Drescher 15-38, 113-125; Curtin 3-15, 127-205; Rawley 149-283. The printed propaganda surrounding the slave trade debate in the period 1780-1807 is discussed in Craton, Sinews 239-285; Davis 388-473; Anstey 142-157, 255-286; a useful anthology of reprinted abolition material is in Craton, Walvin, Wright 1-59. For abolition poetry see Sypher 156-231. For the production of propaganda by women on the middle passage, see Ferguson 180, 198, 218, 224, 236,245 . Little serious work has, as yet, been done on the visual propaganda generated by the slave-trade debate. The 'Description' is briefly described in Walvin 46-47. The two recent books to include some discussion of the SEAST production of imagery are Honour 62-65 (although popular print propaganda, with its problematic relation to high art, is only of tangential importance to this fine study) and, most usefully, Oldfield 155-185.

2 The best overview of the propaganda strategies of the initial campaign 1787-96 is Anstey 256-285. The classic destruction of the 'nursery' argument is contained in Substance 60-112. This work was mainly compiled by Thomas Clarkson out of the material gathered in his interviews in slave ports. For a succinct summary of how Clarkson's research, and this publication in particular, buried the nursery argument see Rawley 286-287.

3 For an assessment of the manner in which this image has come to dominate the popular, and even many scholarly, conceptions of the middle passage see Rawley 283-284 and Walvin 6.

4 The complicated relationship between the early Plymouth Committee version and that of the London Committee has finally been disentangled by Oldfield 99, 163-166. The production of the print in London is discussed in Abolition Committee Minutes 2: 24 March-28 April. For the French and American adaptations see below.

5 Honour 315. For detailed figures on subsequent distribution see Oldfield 165-166, 181-182.

6 For the pro-slavery construction of Africa and Africans see Norris 10-145; Edwards 2: 35-100, 3: 303-360; Long 2: 338-571. For the middle passage see Norris 150-184; Bisset 1: 35-120; Edwards 2: 34-59, 112-122; Long 1: 499-533. For an anlysis of developments in pro-slavery thought see Davis 185-199.

7 While, with the exception of the Stothard plate of the Sable Venus, imagery does not seem to exist, there is a body of pro-slavery literary satire which develops the trope of love and enslavement. A prime example is James Boswell, No Abolition of Slavery or the Universal Empire of Love (1791).

8 The best account of the genesis of the SEAST and its Committee structure, and of the centrality of the London Committee to abolition propaganda strategy is Oldfield 41-50, 96-113. 
9 For a detailed account of the history of Abolition propaganda and the various marketing strategies employed see my forthcoming article 'The Abolition Blunderbuss' in Raven. See also Oldfield 41-59. The best accounts of the cloudy genesis of the SEAST 'Seal,' and its subsequent, though by no means immediate, mass distribution are Honour 314; Oldfield 156-160. There is a fine account of the development and deployment of the women's version of the seal in Yellin 16-30.

10 For extreme examples of the description of atrocity during the middle passage see Anstey 27-33; Clarkson 2: 269.

11 For a recent historical account which equates Newton's metaphor with the 'Description' see Rawley 283.

12 British valorization of the slave patrols after 1807 has not been adequately examined, but is mentioned in Curtin 231-149; Blackburn 313-316, 409-410, 475-476, 545-547; Rawley 419-422. For a Victorian account see Michael 115-159.

13 The woodcut version of the painting reproduced here is from Michael 49.

14 Deane's system was brought to perfection by Frederik Henrik af Chapman, Architechtura Navalis Mercatoria (Stockholm 1768). See also Mansir 8.

15 For the depiction of slave galleys in naval architecture at the time of the plan see Charnock 1: 114, 2: 220. For the type of vessels used in the trade see Stammers 35-42; for the minimal alterations to the boat required to take a slave cargo see Newton, Journal 10-12.

16 The most convenient English overview of Mirabeau's involvement in abolition is Luttrell 199-201. For a more extended but inaccurate account see Smith 2: 138-157. The majority of the text of Mirabeau's planned speech on abolition of the slave trade is printed in Mirabeau 7: 103-208.

17 Wilberforce's model of the Brookes is discussed in Slavery Living History, item G 19/9. The model is on permanent display in Wilberforce House, Hull City Museums and Art Galleries.

18 Encyclopédie Suppl. 1776, 1: 534. This states: 'ARCHE DE NOE, On trouvera dans les Planches d'antiquités Sacrées de ce Supplément, Pl. I un plan de l'arche, qui nous paroit représenter le mieux cet ancien bâtiment. Nous l'avons tiré de la grande Histoire Universelle, traduite de l'anglois, tom. I.'

19 The plate describing the ark is reprinted and discussed in detail in Kocks 131. I am most grateful to Benoit Melançon of the University of Montreal for bringing to my notice the treatment of the ark in the Encyclopédie.

20 Baudrillard 8-19. Baudrillard suggests that Noah's ark is a metaphor which, in its balance and optimism, demands a nemesis. Baudrillard finds that nemesis in contemporary Manhattan: 'This is the anti-Ark, the animals came in two by two to save the species from the great flood. Here in this fabulous Ark, each one comes in alone - it's up to him or her each evening to find the last survivors for the last party.'

21 I am indebted to Philip Lapsansky for my knowledge of the history of the adaptation of this image in the United States. The early examples of the reproduction of the Plymouth Committee's version of the SEAST's original are outlined in Lapsansky 204. 
22 For the pamphlet adaptations of the 'Description' see Lapsansky 204. For later adaptations see Drake 69.

23 Uncle Tom's Almanack 50-51. For later reproductions of the plan see 'Sam' 31.

24 The plan appears on the end-papers of Hennesy.

25 Unsworth, Penguin 1992, still includes the images of the three slaves as a chapter heading device. There is no other use of the 'Description.'

\section{Works Cited}

Abolition Committee Minutes. 3 vols. Add. MSS 21254-56. British Library. London.

Anderson, S. E. The Black Holocaust for Beginners. New York: Writers and Readers Publishing, 1995.

'Arc.' Encyclopaedia Britannica. 3 vols. 1773. 1: 425 and plate opposite.

'Arche de Noë.' Supplément à L'Encyclopédie, ou Dictionnaire Raisonée des Sciences, des Artes et des Métiers. 3 vols. Amsterdam, 1776. 1: 534.

Anstey, Roger. The Atlantic Slave Trade and British Abolition 1760-1810. London: Macmillan, 1975.

'Antiques Judaïques.' Supplément. Vol. 'Planches.' Paris, 1777. Plate 7.

Baudrillard, Jean. America. Trans. Chris Turner. London: Verso, 1987.

Bisset, Robert. The History of the Negro Slave Trade, in its connection with the commerce and prosperity of the West Indies and the Wealth and Power of the British Empire. 2 vols. London, 1805.

Blackburn, Robin. The Overthrow of Colonial Slavery 1776-1848. London: Verso, 1990.

Boswell, James. No Abolition of Slavery or the Universal Empire of Love. London, 1791.

af Chapman, Frederik Henrik. Architechtura Navalis Mercatoria. Stockholm, 1768.

Charnock, John. An History of Marine Architecture ... from the Earliest Period to the Present. 3 vols. London, 1800.

Clarkson, Thomas. The History of the Rise, Progress, and Accomplishment of The Abolition of the African Slave-Trade by the British Parliament. 2 vols. London, 1808.

Craton, Michael. Sinews of Empire: A Short History of British Slavery. London; Temple Smith, 1974.

Craton, Michael, James Walvin, and David Wright. Slavery Abolition and Emancipation. London: Longman, 1976.

Curtin, Philip D. The Atlantic Slave Trade: A Census. Madison: Wisconsin UP, 1969.

Davis, David Brion. The Problem of Slavery in the Age of Revolution 1776-1823. Ithaca: Cornell UP, 1975.

'Description of a Slave Ship.' Broadside with engraving. London: Society for Effecting the Abolition of the Slave Trade, 1789. 
Drake, Richard. Revelations of a Slave Smuggler: Being the Autobiography of Captain Richard Drake, An African Trader. New York, 1860.

Drescher, Seymour. Econocide: British Slavery in the Era of Abolition. Pittsburgh: U of Pittsburgh P, 1977.

Edwards, Bryan. History Civil and Commercial, of the British Colonies in the West Indies. 3 vols. London, 1793.

Ferguson, Moira. Subject to Others: British Women Writers and Colonial Slavery, 1760-1834. London: Routledge, 1992.

Fryer, Peter. Staying Power: The History of Black People in Britain. London: Plato, 1984.

Gates, Henry Louis, Jr. The Signifying Monkey. New York: Oxford UP, 1988.

Honour, Hugh. The Image of the Black in Western Art from the American Revolution to World War I. Cambridge, MA: Harvard UP, 1989.

Kocks, D. 'L'esthétique des planches de l'Encyclopédie.' L'Encyclopédie de Diderot. Ed. Peter-Eckhard Krabe and Edgar Mass. Coll. 'Kolner Schriften zur Romanischen Kultur 2/Textes et Documents.' Verlag Koln, DME, 1985.

Lapsansky, Phillip. 'Graphic Discord: Abolitionist and Anti-abolitionist Images.' Yellin and Van Horne. 200-230.

Long, Edward. The History of Jamaica or, General Survey of the Antient and Modern State of that Island. 3 vols. London, 1774.

Luttrell, Barbara. Mirabeau. Hemel Hempstead: Harvester Wheatsheaf, 1990.

Mansir, Richard A. A Modeler's Guide to Naval Architecture. New York: Moonraker, 1983.

Marley, Bob. Survival. LP album, cover and record sleeve. Island Records, 1979.

Michael, Charles D. The Slave and His Champions. London: S. W. Partridge, 1915.

Miller, Patrick. The Elevation, Section, Plan and Views, of a Triple Vessel, and of Wheels with Explanations of the Figures in the Engraving. Edinburgh, 1787.

Mirabeau, Gabriel-Honoréde Riquetti, comte de. Mémoires Biographiques, Littéraires et Politiques de Mirabeau Écrits par Lui-Même, Par son Père, son oncle et son fils adoptif. 8 vols. Paris, 1834.

Newton, John. The Journal of a Slave Trader. Ed. and intro. Bernard Martin and Mark Spurrell. London: Epworth P, 1962.

.Thoughts Upon the African Slave Trade. London, 1788.

Norris, Robert. Memoirs of the reign of Bossa Ahadee, King of Dahomey, An INLAND COUNTRY of GUINEA. To Which are Added the Author's Journey to Abomey, the Capital; and A short Account of the African Slave Trade. London, 1789.

Oldfield, J. R. Popular Politics and British Anti-Slavery: The Mobilisation of Public Opinion Against the Slave Trade 1787-1807. Manchester: Manchester UP, 1995.

'Plan of an African Ship's Lower Deck with Negroes in the proportion of only One to a Ton.' Broadside with engraving. Plymouth: Plymouth Committee for Effecting the Abolition of the Slave Trade, 1788.

Rawley, James A. The Transatlantic Slave Trade. New York and London: Norton, 1981. 
Slavery Living History Fact Pack. Ed. Elizabeth Frostick. Hull: Wilberforce House, Hull City Museums and Art Galleries, 1989.

Smith, John Stores. Mirabeau: A Life History. 2 vols. London, 1848.

Stammers, M. K. 'Guineamen: Some Technical Aspects of Slave Ships.' Transatlantic Slavery Against Human Dignity. Exh. cat. Ed. Anthony Tibbles. London: HMSO, 1994.

The Substance of the Evidence of Sundry Persons on the Slave Trade Collected in the Course of a Tour Made in the Autumn of the Year 1788. London: James Phillips, 1789.

“Sam,' A Genuine 'Dicky." Liverpool and Slavery. Liverpool, 1884.

Sulivan, G. L. Dhow Chasing in Zanzibar Waters and on the Eastern Coast of Africa Narrative of five years' experiences in the suppression of the slave trade. London, 1875.

Sypher, Wylie. Guinea's Captive Kings: British Anti-Slavery Literature of the xviii'th Century. Chapel Hill: U of North Carolina P, 1942.

Taylor, Isaac. Scenes in Africa for the Amusement and Instruction of Little Tarry at Home Travellers By the Reverend Isaac Taylor. New York, 1827.

The Uncle Tom's Cabin Almanack or Abolitionist Memento. London, 1853.

Unsworth, Barry. Sacred Hunger. London: Penguin, 1992. Hardcover and paperback editions.

Walvin, James. Black Ivory: A History of British Slavery. London: Harper Collins, 1992.

Wilkins, John. An essay towards a real character and a philosophical language. London, 1688.

Williams, Gomer. History of the Liverpool Privateers ... With an Account of the Liverpool Slave Trade. London, 1897.

Wood, Marcus. 'The Abolition Blunderbuss.' Free Publishing. Ed. James Raven. Minneapolis: $U$ of Minn P. Forthcoming.

Yellin, Jean Fagan. Women and Sisters. New Haven: Yale UP, 1989. and John C. Van Horne, eds. The Abolitionist Sisterhood: Women's Political Culture in Ante-bellum America. Ithaca: Cornell UP, 1994. In collaboration with the Library Company of Philadelphia. 